\title{
Role of dietary supplementation of methionine and Folic acid in early atherosclerotic Changes in adult male mice
}

\author{
Marwa Abd EL-Aziz Ahmed, Manal Mohamed Sead*, \\ Ola Mohamoud Omran** and Heba Mohamed Said* \\ Physiology Department, Histology Department *and Pathology \\ Department**, Faculty of Medicine, Assiut University.
}

\begin{abstract}
Background: Homocysteine (Hcy) is an important intermediate product in normal metabolism of methionine. On the other hand, several studies have reported beneficial effects of folate on endothelial dysfunction. However the exact mechanism remains to be elucidated. Thus the objective of this study was to asses the relationship between total plasma Homocysteine (tHcy) and early atherosclerotic changes and whether Hcy exerts its effect through the vascular adhesion molecule (VCAM-1) or not. Study Design: Forty adult male mice were randomly divided into 4 groups, each group included 10 mice. Control group which received the control diet. Group II: which received the control diet plus methionine dissolved in drinking water (4.4\%) at doses of 3-4 ml/day/mice for 8 weeks. Group III: received the control diet and methionine by the same previous dose and duration, concomitant with folic acid in a dose $1 \mathrm{mg} / \mathrm{kg}$. Group IV: received the control diet and methionine by the same previous dose and duration then followed by folic acid in the same previous dose for another 8 weeks. Blood samples were taken for estimation of tHcy,total cholesterol (TC), High density lipoprotien (HDL),Low density lipoprotein (LDL), nitric oxide $(N O)$, superoxide dismutase (SOD). Specimens from aorta were taken and processed for imunohistochemical staining of VCAM-1 and histopathological examination. Results: The plasma level of Hcy and cholesterol of group II were significantly higher than those of the remaining groups and there was a positive correlation between plasma level of Hcy and cholesterol. Although there was no significant difference between group I and group III, there was a significant difference of these levels between group I and group IV. Plasma levels of $L D L, H D L$ and triglycerides did not differ statistically between all studied groups. Plasma levels of NO in group II was significantly lower than the other studied group. Its levels in group I was significantly higher than that of group III and group IV. Plasma levels of SOD of group II was significantly lower than the other studied group. Although there was no significant difference between NO levels of group I and group III, there was a significant difference of these levels between group I and group IV. As regard the endothelial VCAM-1 expression, marked increase in the expression of VCAM-1 in group II. Low expression in group III (similar to the groupI). Moderate expression of group IV. The high expression of VCAM-1 in group II might be responsible for the observed histological changes; thickening of the aortic wall and adherent inflammatory cells to the irregular endothelial lining. Conclusion: Elevated plasma homocysteine is a risk factor for early atherosclerosis which was confirmed by the endothelial expression of VCAM-1. Prophylactic administration of folic acid has a beneficial effect more than its role as a treatment.
\end{abstract}




\section{INTRODUCTION}

Homocysteine (Hcy) is a thiol amino acid that lies at a critical branch point in methionine metabolism. In most tissues, methionine is activated by ATP to form Sadenosylmethionine(SAM). A major product of SAM-dependent methyl transfer reactions is $\mathrm{S}$ adenosylhomocysteine (SAH), which can undergo hydrolysis to form Hcy. Hcy can either undergo condensation with serine to form cystathionine, or undergo remethylation to form methionine. In most tissues, the major pathway for homocysteine remethylation is catalyzed by the vitamin B12-dependent enzyme methionine synthase (MS).This reaction utilizes 5 methyltetrahydrofolate, which is generated by 5,10-methylene tetrahydrofolate reductase $(\mathrm{MTHFR})^{(\mathbf{1})}$.

Atherothrombosis is a complex, chronic process that is initiated at sites of endothelial cell injury and culminates in atherosclerotic lesion disruption with superimposed thrombus formation ${ }^{(2)}$. Hyperhomocysteinemia (HHcy) is a pathological condition characterized by an increase in plasma concentration of total homocysteine (tHcy). Numerous clinical and epidemiological studies have indicated that HHcy is an independent risk factor for atherothrombotic disease $^{(3)}$. Furthermore, a direct causal relationship between induction of HHcy and accelerated atherosclerosis has been reported ${ }^{(4)}$.
Adhesion of circulating monocytes to endothelial cells is early step in the atherosclerotic process and is mediated by inducible cell adhesion molecules such as intercellular adhesion molecule (ICAM)-1 and vascular cell adhesion molecule (VCAM)-1, which are expressed on the surface of endothelial cells. Increased expression of adhesion molecules is observed in atherosclerotic lesions and plaque ${ }^{(5)}$.

The inflammatory molecules, including monocyte chemoattractant protein-1(MCP-1), VCAM-1, ICAM1 and E-selectin, have been proposed as key elements in this inflammatory responses and Hcy affects the expression of some inflammatory factors in both aortic endothelial cells $^{(6)}$ and monocytes ${ }^{(7)}$.

Verharr et al. $^{(\mathbf{8})}$ reported that folates may play a role in the prevention of cardiovascular disease and several studies have reported beneficial effects of folates on endothelial function. However the exact mechanisms underlying the ameliorative effects of folates on the endothelium remain to be elucidated. Thus far, most studies have focused on the Hcy lowering effects of folates.

Aim of the work:

To assess the relationship between plasma t-Hcy and early endothelial changes in adult male mice and to determine if Hcy exerts its effect through the VCAM-1 or not.

Relationship between plasma tHcy and folic acid, also determination of the effect of folic acid in preventing and treating the early atherosclerotic changes were also evaluated. 


\section{MATERIALS \& METHODS}

\section{Chemicals:}

\section{L-Methionin was supplied from} Titan Biotech limited.

Kits:

1. Assay kits for estimation of plasma levels of t-Hcy by ELIZA kit supplied by IBL GmbHFlubhafenstrasse 52A-D $=22335$ Hamburg, Germany.

2. Total cholesterol kit: Enzymatic colorimeteric kit supplied from Stanbio Laboratory Inc.

3.Triglycerides kit: Enzymatic colorimeteric triglyceride kit supplied from Stanbio Laboratory Inc.

4.HDL-cholesterol kit: Enzymatic colorimeteric HDL-cholesterol kit supplied from Stanbio Laboratory Inc.

5. VCAM-1: supplied from Santa Cruze Biotechnology.

Animals:

Forty mice with body weight 24 $27 \mathrm{~g}$ were obtained from the Animal House in Faculty of Medicine in Assiut University . Mice were housed under condition of controlled temperature $\left(24-26^{\circ} \mathrm{C}\right)$, humidity (55-60 \%) and at natural photobic periods for one week before the start of the experiment. A commercial balanced diet and tap water adlibitum were provided to all animals. After the adaptaion period the animals were randomly divided into:

1. Group I: included 10 mice (represented the control animals).

2. Group II: included 10 mice received methionine. The concentration of methionine in drinking water was adjusted to deliver a total of $4.4 \%$ methionine / L drinkinig water for 8 weeks and the doses were calculated assuming an average water intake of 3 to $4 \mathrm{~mL} / \mathrm{d}$ and an average body weight of $25 \mathrm{~g}$. The concentration was changed every 3 days to deliver approximately the same dose based on average water intake $^{(4)}$.

3. Group III: included 10 treated mice with methionine by the same dose of group II + folic acid $(1 \mathrm{mg} / \mathrm{kg})$ for 8 weeks.

4. Group IV: included 10 mice treated with methionine for 8 weeks then followed by intake of folic acid in a dose of $(1 \mathrm{mg} / \mathrm{kg})$ for another 8 weeks.

At the end of study, all the animals were sacrificed and blood samples from all the animals were collected via retro- orbital puncture (optic vien). Non fasting blood samples were obtained in chilled EDTA-containing microtubes and centrifuged immediately and the plasma were divided into two aliquots, first aliquot was stored at $20{ }^{\circ} \mathrm{C}$ until analysis.

The buffy coat from $2^{\text {nd }}$ aliquot was discarded and RBCs were washed 3 times with saline and were hemolysed with an equal amount of distilled water for determination of enzymatic activities of erythrocytic superoxide dismutase (Ery.SOD).

Plasma was analyzed for levels of t-Hcy by ELIZA technique kit according to Frantzen et $\mathrm{al}^{(\mathbf{9})}$, plasma levels of total cholesterol by colorimeteric method according to the method of Allain ${ }^{(\mathbf{1 0})}$ and triglycerides levels according to the method of Wahlefeld ${ }^{(\mathbf{1 1})}$. Determination of HDL-C level was based on kit colorimeteric method 
described by Finely ${ }^{(12)}$. LDL-C calculated according to Feidewald ${ }^{(13)}$.

Level of Nitric oxide(NO) in plasma was determined by the evaluation of its oxidant products, nitrates and nitrites by using Griess reaction $^{(\mathbf{1 4})}$. Determination of Ery.SOD activity according to Misra and Fridovich ${ }^{(15)}$.

The thoracic aorta was isolated immediately from all sacrificed mice and divided into segments which were taken for histological immunohistochemical examination.

\section{Statistical Analysis:}

All values were expressed as mean \pm SE. Differences between groups were determined by Student's Newman Kelus t test. Values were considered insignificant if $\mathrm{P}$ value is $>0.05$ and significant if $P$ value is $<$ 0.05 .Simple linear correlation was performed to analyze the relation between plasma Hcy and plasmatic levels of cholesterol. Prism computer program (graph $\mathrm{Pab}$ version 3.0) is used for statistical analysis ${ }^{(\mathbf{1 6})}$.

\section{Histopathological examination:}

Specimens from aorta were immersion-fixed in $10 \%$ neutralbuffered formalin overnight and then embedded in paraffin, sectioned at 5 $u m$ and stained with haemotoxlyin and eosin(H\&E) then were examined with light microscopy for histological structure.

Other Specimens were examined by immunohistochemical method using VCAM-1 kit.

\section{Immunohistochemistry}

\section{Examination:}

VCAM-1 expression was determined on paraffin sectioned ( $5 \mathrm{~mm}$ thick) of the aorta blocked with $10 \%$ horse serum and incubated with primary antibody (polyclonal goat antimouse VCAM-1 of $5 \mathrm{mg} / \mathrm{ml}$ overnight at $4{ }^{\circ} \mathrm{C}$ followed by biotinconjugated horse antigoat antibody, avidin-biotin complex, and 3, 39diaminobenzidine as substrate. Photographs were taken by use of a light microscopy at a magnification of X 1000 .

\section{RESULTS}

\section{I-Biochemical Data:}

Table (1) shows mean values \pm SE of plasma levels of t-Hcy in all the studied groups. It was observed that the mean plasma level of t-Hcy in group II was $17.25 \pm 0.496 \mathrm{umol} / \mathrm{L}$ which was significantly higher than those of group I, group III and group $\operatorname{IV}(17.25 \pm 0.49 \mathrm{umol} / \mathrm{L}$ versus 10.05 $\pm 0.12 \mathrm{umol} / \mathrm{L}, \quad 10.15 \pm 0.15 \mathrm{umol} / \mathrm{L}$, $10.54 \pm 0.09 \quad$ umol/L, $\quad \mathrm{P}>0.001$ respectively). Also the plasma levels of Hcy of group IV was significantly higher than those of group I and group III $(10.54 \pm 0.09 \mathrm{umol} / \mathrm{L}$ versus 10.05 $\pm 0.12 \mathrm{umol} / \mathrm{L}$ and $10.15 \pm 0.15 \mathrm{umol} / \mathrm{L}$, $\mathrm{P}<0.05, \quad \mathrm{P}<0.01 \quad$ respectively). Although there was no significant difference between plasma levels of tHcy of group I and group III.

From table (1) it is clear that plasma level of total cholesterol (TC) of group II was significantly higher than those of group I, group III and group IV $(158.5 \pm 7.22 \mathrm{mg} / \mathrm{dl}$ versus $101.1 \pm 2.58 \mathrm{mg} / \mathrm{dl}, 103.1 \pm 2.6 \mathrm{mg} / \mathrm{dl}$, $112.5 \pm 3.27 \mathrm{mg} / \mathrm{dl}, \quad \mathrm{P}>0.001$, respectively). The plasma levels of TC of group IV was higher than those of group I and group III (112.5 \pm 3.27 $\mathrm{mg} / \mathrm{dl}$ versus101.1 $2.58 \mathrm{mg} / \mathrm{dl}$, $103.1 \pm \quad 2.6 \mathrm{mg} / \mathrm{dl}, \quad \mathrm{P}<0.05$, respectively). Also there was no 
significant difference between plasma levels of TC of group I and group III

Figure (1) shows that there was a significant correlation between the plasma levels of t-Hcy and plasma levels of TC in group II ( $\mathrm{r}=0.8894$, $\mathrm{n}=10$ with $\mathrm{P}>0.001)$. Although there were no correlations between the plasma levels of t-Hcy and plasma levels of TC in the other groups.

There were no significant differences between the mean concentrations of HDL-C in the plasma of group I, group II, group III and group IV which were $(27.94 \pm 1.9$ $\mathrm{mg} / \mathrm{dl}, 25.82 \pm 1.4 \mathrm{mg} / \mathrm{dl}, 27.8 \pm 1.5$ $\mathrm{mg} / \mathrm{dl}, 25.91 \pm 1.3 \mathrm{mg} / \mathrm{dl}$, respectively).

The mean concentrations of LDL$\mathrm{C}$ in the plasma of group I, group II, group III and group IV $(58.51 \pm 2.932$ $\mathrm{mg} / \mathrm{dl}, 65.24 \pm 3.3 \mathrm{mg} / \mathrm{dl}, 60.25 \pm 1.64$ $\mathrm{mg} / \mathrm{dl}, 62.6 \pm 2.4 \mathrm{mg} / \mathrm{dl}$ respectively) did not show significant differences between the different studied groups.

The mean plasma levels of triglycerides of group I, group II, group III and group IV (73.29 \pm 2.59 $\mathrm{mg} / \mathrm{dl}, 77.3 \pm 2.4 \mathrm{mg} / \mathrm{dl}, 70.67 \pm 3.2$ $\mathrm{mg} / \mathrm{dl}$ and $72.7 \pm 1.9 \mathrm{mg} / \mathrm{dl}$ respectively) did not differ statistically.

Table (2) and figure (2) show that the mean plasma levels of $\mathrm{NO}$ in group I was $13.67 \pm 0.49$ umol/1. The mean plasma levels of NO in group II was significantly lower than that of group I, group III and group IV ( $7.69 \pm 0.19 \mathrm{umol} / \mathrm{l}$. versus $13.67 \pm 0.49$ umol/l., $12.54 \pm 0.27 \mathrm{umol} / \mathrm{l}$. and $10.26 \pm 0.15 \mathrm{umol} / 1 \quad, \quad \mathrm{P}>0.001$ respectively). The mean plasma levels of NO in group I was significantly higher than that of group III and group IV $(13.67 \pm 0.49 \mathrm{umol} / \mathrm{L}$ versus 12.54 $\pm 0.27 \mathrm{umol} / \mathrm{L}$, and $10.26 \pm 0.15$
umol/L, $\quad \mathrm{P}>0.05, \quad$ P.0.001, respectively). Also the mean plasma levels of NO in group III was significantly higher than that of group IV $12.54 \pm 0.27 \mathrm{umol} / \mathrm{L}$ versus $10.26 \pm$ $0.15 \mathrm{umol} / \mathrm{L}, \mathrm{P}>0.001$, respectively).

In this study the levels of Ery.SOD were also determined in all studied groups. The levels of Ery. SOD of group II was significantly lower than that of group I, group III and group IV $(17.69 \pm 1.7 \mathrm{U} / \mathrm{gm} \mathrm{Hb}$ versus $33.7 \pm 2.7 \mathrm{U} / \mathrm{gm} \mathrm{Hb}, 32.2 \pm$ $2.9 \mathrm{U} / \mathrm{gm} \mathrm{Hb}$ and $25.19 \pm 1.7 \mathrm{U} / \mathrm{gm} \mathrm{Hb}$ versus, $\mathrm{P}>0.001, \mathrm{P}>0.001$ and $\mathrm{P}>0.01$, respectively). The levels of Ery. SOD of group I was significantly higher than that of group IV $(33.7 \pm 2.7 \mathrm{U} / \mathrm{gm}$ $\mathrm{Hb}$ versus $25.19 \pm 1.7 \mathrm{U} / \mathrm{gm} \mathrm{Hb}$, $\mathrm{P}>0.05$ ). There was no significant difference between levels of Ery. SOD of group I and that of group III. Moreover there was no significant difference between levels of Ery.SOD of group III and that of group IV. All data concerned of levels of Ery.SOD are shown in table (3) and figure (3).

\section{II-Histological \\ Immunohistochemical results: Group I:}

The wall of the aorta in these animals is formed of the usual 3 layers :a) Tunica intima with characteristic single squamous epithelium and delicate sub endothelial tissues. b)Tunica media that is formed of several layers of smooth muscle fibers intermingled with large amount of elastic fibers c) Tunica adventia is formed of loose connective tissues rich in elastic fibers .(Fig. A).

Immunohistochemical method for detection of VCAM-1 in the endothelial cell monolayer 
demonstrates minimal reaction (Fig. B).

\section{Group II:}

There is increase of the thickness of aortic wall, marked irregularity in the endothelial layer which is covered with large number of attached inflammatory cells (lymphocytes and monocytes) attached to the markedly irregular endotheial layer. There is marked increase of waviness of elastic fibers (Fig. C).

The detection of VCAM-1in the aorta isolated from group II demonstrates highly positive reaction in the endothelial cell of and in the macrophages derived foam cell (F) (Fig. D).

\section{Group III:}

The thickness of the aortic wall looks similar to the control (group I). The tunica intima looks like those of the control (apart of from inflammatory cells aggregated in the sub endothelial layer) and tunica media also looks like those of the control group (Fig.E).

Immunohistochemical method for detection of VCAM-1 in the endothelial cell demonstrates a low positive reaction slightly higher than that of control (Fig. F).

Group IV: There is increase in the thickness of the aortic wall, there is irregularity in the endothelial layer but no detectable inflammatory cells. The tunica media looks more or less similar to the control (Fig.G).

Detection of VCAM-1 in the endothelial cell demonstrates moderate positive reaction. Migrating macrophages is observed toward an area of perforation in the endothelial layer (Fig. H).

Table (1): Plasma levels of total homocysteine and cholesterol in all studied groups of mice

\begin{tabular}{|l|l|l|l|l|}
\hline Groups & Group I & Group II & Group III & Group IV \\
\hline Parameter & & & & \\
\hline Hcy (umol/L) & $10.05 \pm 0.12$ & $17.25 \pm 0.49^{\mathrm{a}, \mathrm{d}, \mathrm{f}}$ & $10.15 \pm 0.15^{\mathrm{c}}$ & $10.54 \pm 0.09^{\mathrm{b}, \mathrm{e}}$ \\
\hline
\end{tabular}

Values are mean \pm SEM for 10 mice each group
a: $P \leq 0.001$ as compared to group $I$
$d: P \leq 0.001$ as compared to group III
$b: P \leq 0.05$ as compared to group I
e: $P \leq 0.05$ as compared to group III
c: Non significant as compared to group I
$f: P \leq 0.001$ as compared to group $I V$

Table (2): Plasma levels of Nitric oxide (umol/L) in the studied groups

\begin{tabular}{|c|c|c|c|c|}
\hline Groups & Group I & Group II & Group III & Group IV \\
\hline $\begin{array}{l}\text { Plasma levels of } \\
\text { NO (umol/L) }\end{array}$ & $13.67 \pm 0.49$ & $7.69 \pm 0.19^{\mathrm{a}}$ & $12.54 \pm 0.27^{\mathrm{b}, \mathrm{c}, \mathrm{e}}$ & $10.26 \pm 0.15^{\mathrm{c}, \mathrm{e}}$ \\
\hline $\begin{array}{l}a: P \leq 0.001 \text { as com } \\
b: P \leq 0.05 \text { as comp } \\
c: P \leq 0.001 \text { as comp }\end{array}$ & $\begin{array}{l}\text { ed to group } \\
\text { ed to group }\end{array}$ & & \multicolumn{2}{|c|}{$\begin{array}{l}d: P \leq 0.05 \text { as compared to group II } \\
e: P \leq 0.05 \text { as compared to group IV }\end{array}$} \\
\hline
\end{tabular}


Table (3):Plasma levels of Superoxide dismutase (U/gm Hb) in all studied groups

\begin{tabular}{|c|c|c|c|c|}
\hline Groups & Group I & Group II & Group III & Group IV \\
\hline $\begin{array}{l}\text { Plasma levels of SOD } \\
(\mathrm{U} / \mathrm{gm} \mathrm{Hg})\end{array}$ & $33.7 \pm 2.7$ & $17.69 \pm 1.7^{\mathrm{a}}$ & $32.2 \pm 2.9^{\mathrm{c}, \mathrm{d}, \mathrm{f}}$ & $25.19 \pm 1.7^{\mathrm{b}, \mathrm{e}}$ \\
\hline $\begin{array}{l}b: P \leq 0.01 \text { as compared } \\
c: \text { Non significant as cor }\end{array}$ & $\begin{array}{l}\text { up I } \\
p I \\
\text { to group }\end{array}$ & $\begin{array}{l}e: P \leq \\
f: P \leq\end{array}$ & $\begin{array}{l}05 \text { as compa } \\
95 \text { as compa }\end{array}$ & $\begin{array}{l}\text { ed to group } 1 \\
\text { to group } I I \\
\text { to group } I V\end{array}$ \\
\hline
\end{tabular}

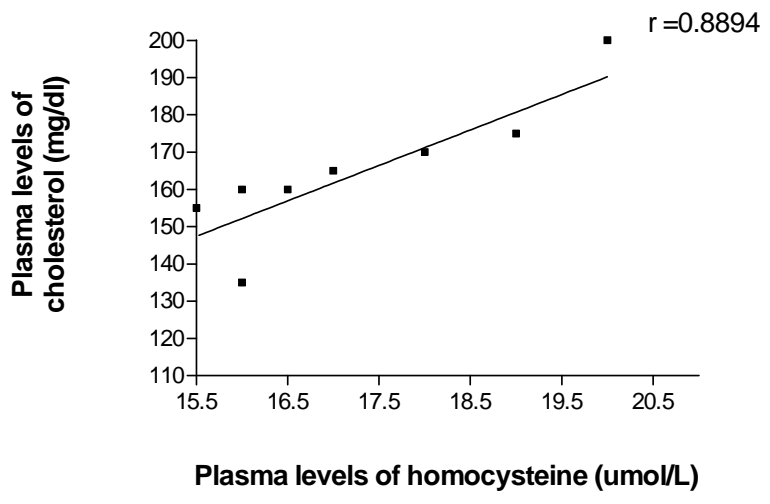

Figure (1): Correlation between plasma levels of cholesterol (mg/dl) and plasma levels of total homocysteine (umol/L) in group II

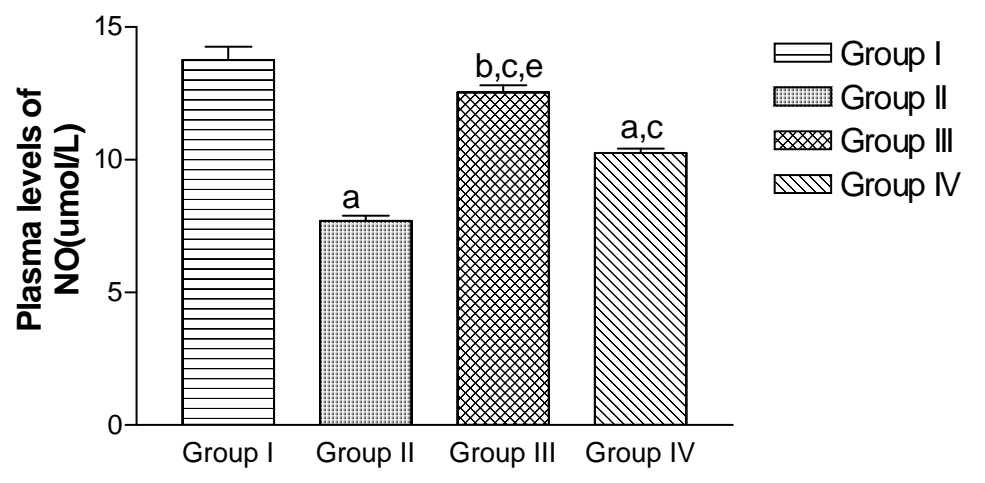

Figure (2): Plasma levels of Nitric oxide (NO) in group I, group II, group III and group IV
a: $P \leq 0.001$ as compared to group I
$b: P \leq 0.05$ as compared to group $I$
$d: P \leq 0.05$ as compared to group II
$c: P \leq 0.001$ as compared to group II
$e: P \leq 0.05$ as compared to group IV 


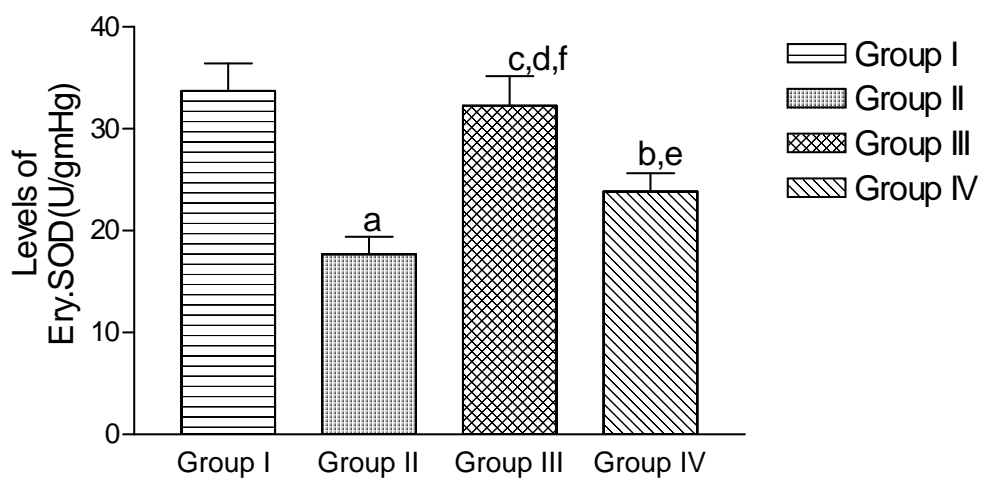

Fig. (3): Levels of Ery. SOD (U/gmHb) in group I, II, III and group IV

a: $P \leq 0.001$ as compared to group I

$b: P \leq 0.01$ as compared to group I

$c$ : Non significant as compared to group I $d: P \leq 0.001$ as compared to group II $e: P \leq 0.05$ as compared to group II $f: P \leq 0.05$ as compared to group $I V$

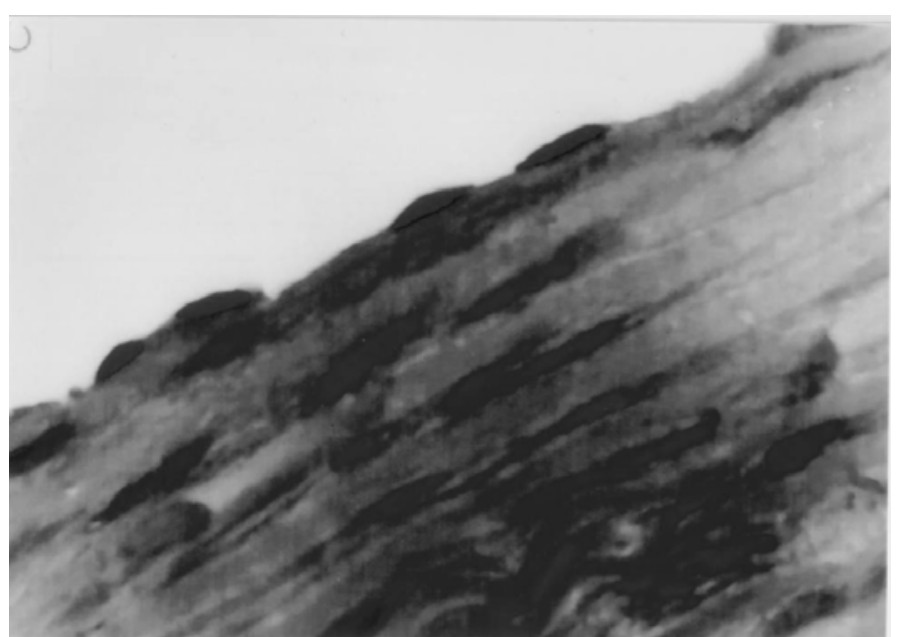

Fig (A): A paraffin magnified section of the aorta of group I showing tunica intima and media (H\& $E X$ 1000) 


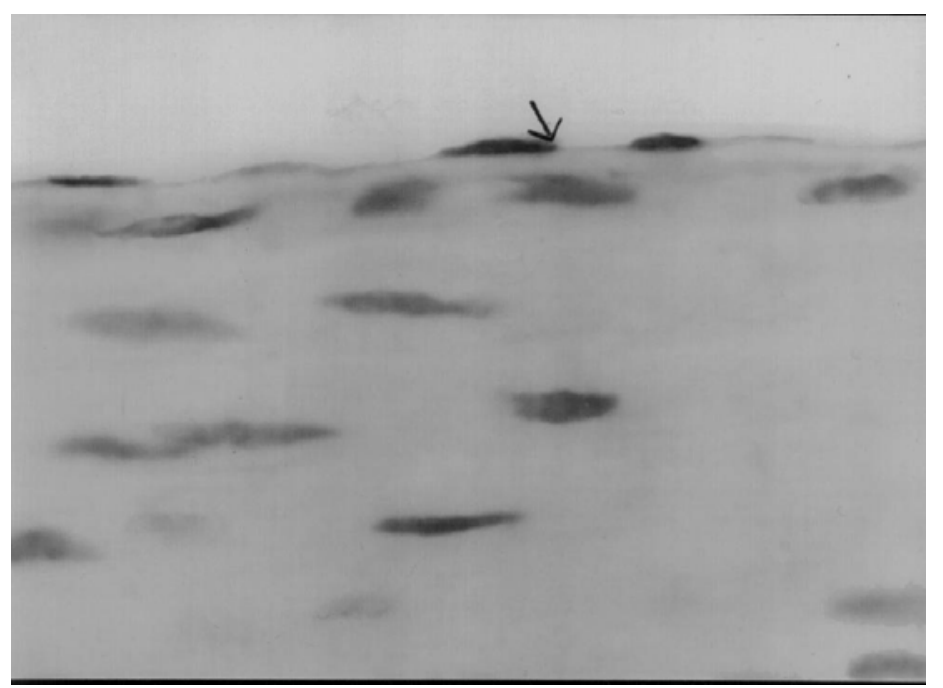

Fig (B): Immunohistochemical method for detection of VCAM-1 in the aorta of group I showing minimal expression of the adhesion molecules in the endothelial layer monolayer (arrow). (X1000).

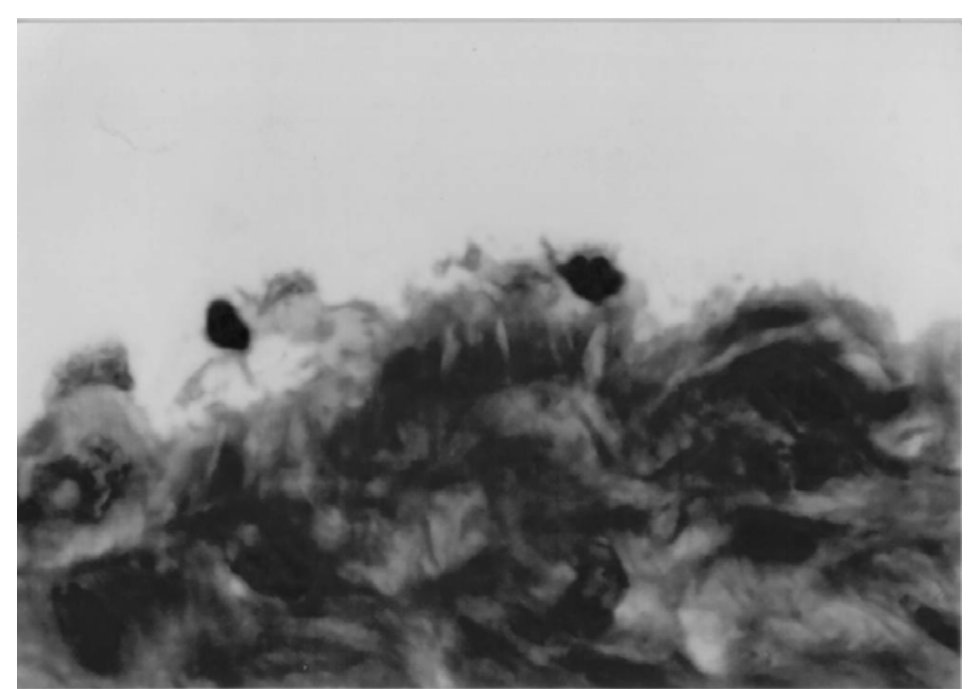

Fig (C): A paraffin magnified section of the aorta of group II showing inflammatory cells (Lymphocyte \& monocyte) attached to the markedly irregular endothelial layer. (H \&E X 1000) 


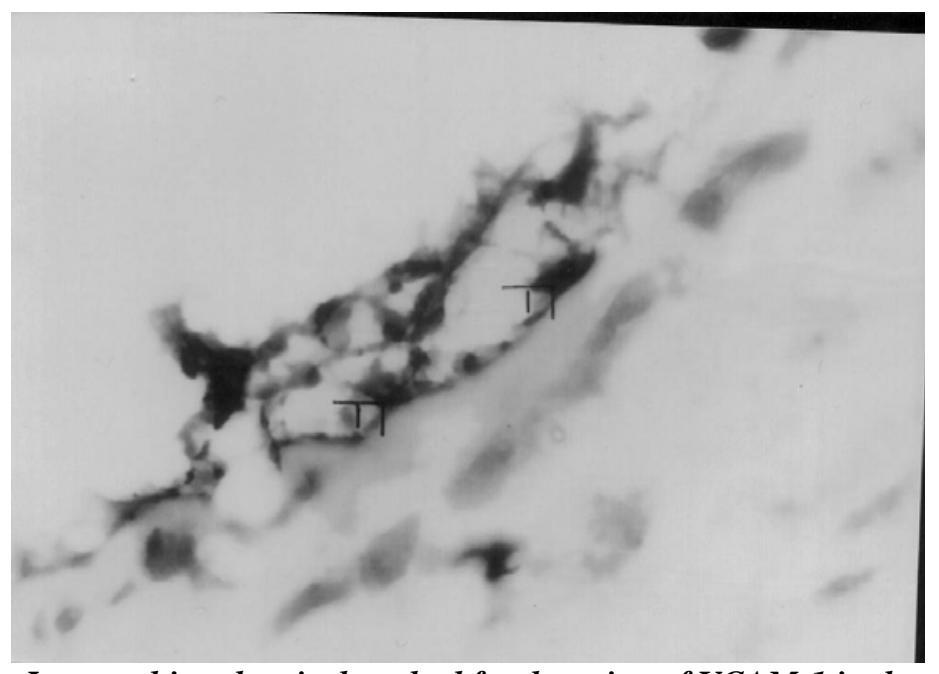

Fig (D): Immunohistochemical method for detection of VCAM-1 in the aorta of group II showing marked expression of the adhesion molecules in the endothelial cells and the intimal macrophages derived foam cells.(F). (X 1000).

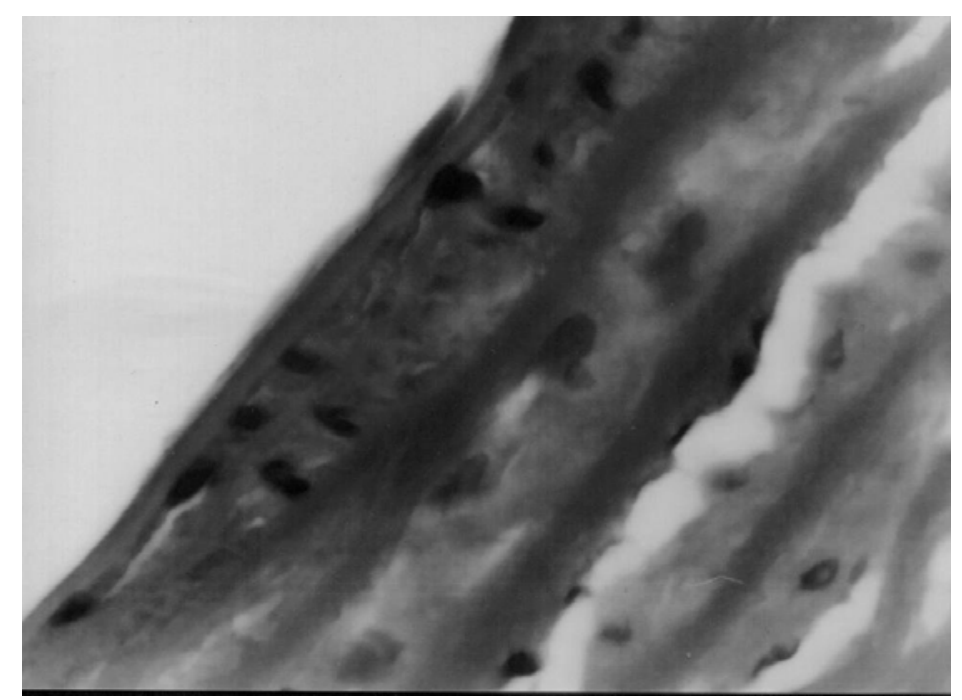

Fig (E): Magnified section in the aorta of group III animals showing the tunica intima looks like those of control apart from the inflammatory cells aggregated in the sub endothelial layer (H\& E X 1000) 


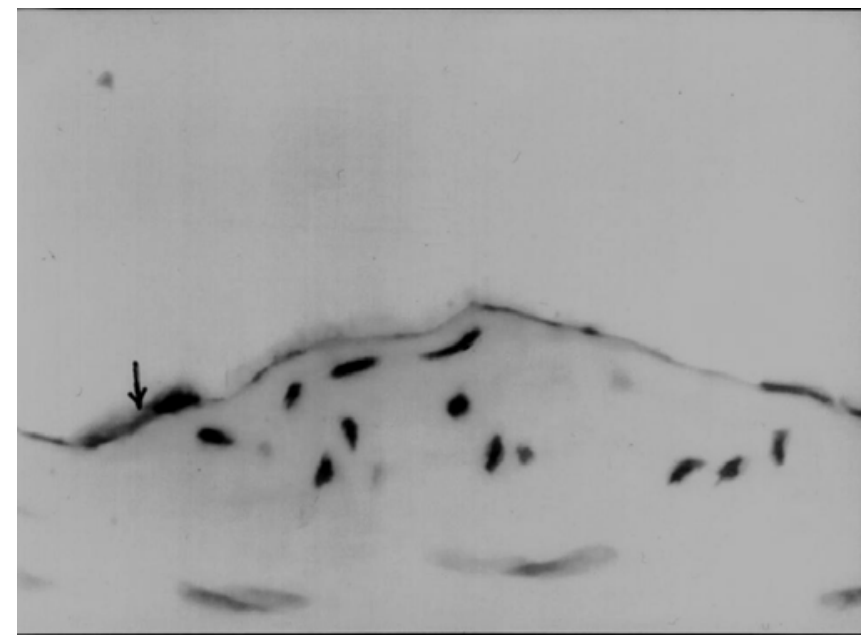

Fig (F): Immunohistochemical method for detection of VCAM-1 in the aorta of group III showing low expression of the adhesion molecules (arrow)and denude sites began to rendotheliazed $(X$ 1000).

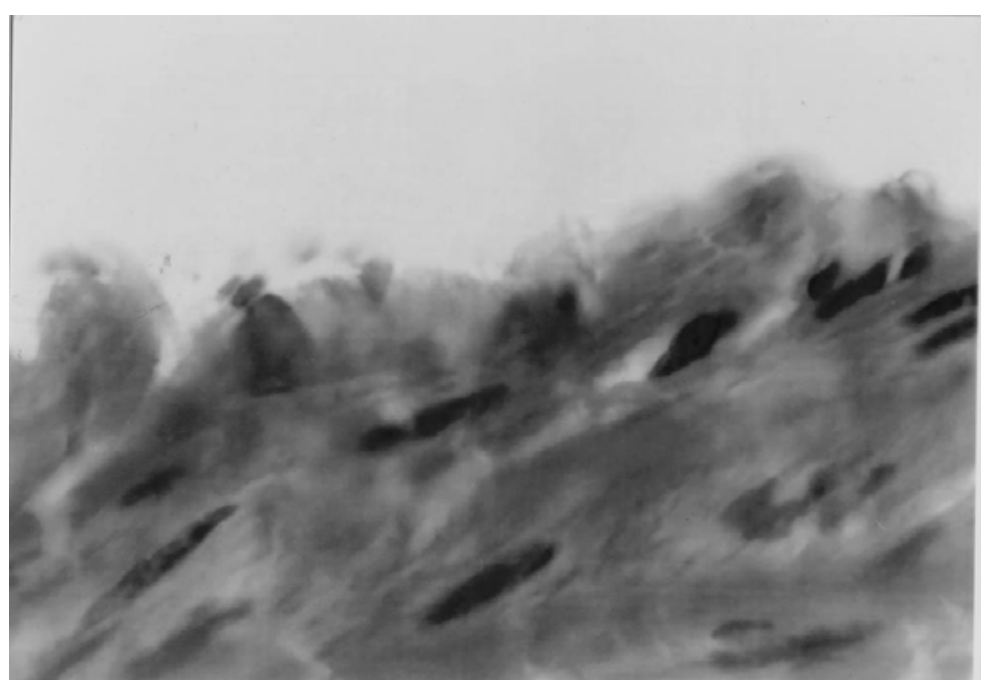

Fig (G): A paraffin magnified section the aorta of group IV animals showing irregularity in the endothelial layer but with no detectable inflammatory cells. (H\&E X1000) 


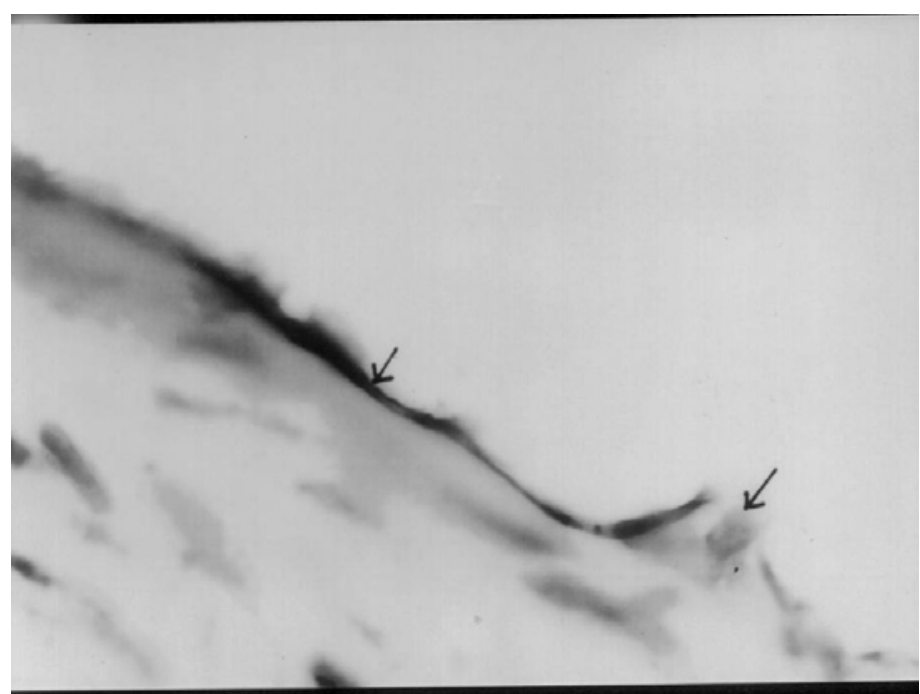

Fig (H): Immunohistochemical method for detection of VCAM-1 in the aorta of group IV showing moderate expression of the adhesion molecule in the endothelial cell. Macrophages migrating through endothelial cells (arrow). (X1000).

\section{DISCUSSION}

The present study was designed to determine if elevated plasma levels of tHcy in mice causes early atherosclerotic changes of the vascular endothelium characterized by increased expression of VCAM-I or not. The most striking finding of this study was that plasma levels of t-Hcy in group II are significantly higher than those of group I group III, and group IV. The results showed that in this group there were endothelial dysfunction in the form of leukocytes and monocytes adhesion and this was due to the HHcys. This HHcy was explained by Hirche et al. ${ }^{(17)}$, who reported that methionine was metabolized to produce homocysteine via S- adenosyl homocysteine. In addition, methionine and its intermediate product can inhibit homocysteine methyltransferase and thereby block the metabolism of Hcy, leading to increased plasma t-Hcy levels. It was also observed in this work that HHcy of group II causes early changes of atherosclerosis through stimulation of expression of VCAM-I in the endothelial layer and in macrophages derived foam cells. This was associated with adherent inflammatory cells to the denuded vascular endothelium and increased intima -media thickness which is in accordance with Stray et al. ${ }^{(18)}$ who reported that an inflammatory lesion, consisting only of monocyte-derived macrophages and $\mathrm{T}$ lymphocytes, is considered the earliest stage of atherosclerotic lesion

There was no significant difference between plasma levels of tHcy of group I and group III. This findings showed that supplementation 
of folic acid as a prophylaxis for group III decreased the plasma levels of t-Hcy to the control levels which was accompanied by low expression of VCAM-I in the aortic wall. The thickness of the wall of the aorta looks like that of group I, this is explained by that folate has a Hcy lowering effect by its action as a substrate in remethylation of Hcy to methionine which prevented the high level of VCAM-I expression. Plasma levels of tHcy of group IV were significantly higher than those of group I and group III which were associated with moderate expression of VCAM-1 and improvement in the denuded vascular endothelium This means that folic when used as a prophylaxis has better lowering effect of plasma levels of tHcy and its associated atherosclerotic changes than used as a treatment for HHcy.

The present study shows that dietary intake of methionine for 8 weeks has a hypercholesterolemic action when added to cholesterol-free diet in adult mice, as the plasma level of TC in group II was significantly higher than that of group I, group III and group IV. Moreover, there was a significant correlation between the plasma levels of Hcy and TC in group II. This was evidenced by presence of foam cells. However, group II of mice did not show distinct alternations in concentrations of plasma lipoproteins and triglycerides and did not show plaque formation through out the sections of abdominal aorta studied. These results are in accordance with previous studies by Zulli et al. ${ }^{\mathbf{( 1 9 )}}$. Hirche et al. ${ }^{(17)}$ who explained this hyperchloestremia by that dietary intake of methionine causes HHcy which induces activation of cholesterol synthesis, not by down regulating LDL receptors or change LDL uptake. Hcy activates the transcription factors sterol regulatory element binding protein -2 (SREBP 2) and cAMP response element binding protein which play a key role in cholesterol synthesis. On the other hand, the alternation in the methionine/Hcy pathway are also believed to have hypercholesterolemic action by increasing the phosphatidylcholine:

phosphatidylethanolamine ratio in the liver, which in turn raises the concentration of cholesterol in plasma.

The plasma cholesterol levels of group I and III did not show significant alternations however, that of group IV which was supplemented with folic acid as a treatment was decreased from that of group II but still significantly higher than that of group I and III. This shows that folic acid has a beneficial effect when used as a prophlayctic.

Endothelial dysfunction, a crucial early event in atherogenesis, is characterized by reduced bioavailability of $\mathrm{NO}^{(\mathbf{8})}$.This study reported that plasma levels of $\mathrm{NO}$ of group II were significantly decreased than levels of other studied groups, and this in accordance with Lentz ${ }^{(20)}$ who reported of experimental HHcy causes impairment of vasodilation mediated by endothelium-derived nitric oxide This was explained by that expression of eNOS does not appear to be decreased during HHcy so it appears that HHcy decreases nitric oxide bioavailability through increasing levels of reactive oxygen 
species (ROS), which contribute to the oxidative inactivation of endothelium-derived nitric oxide in $\mathrm{HHcy}^{(21)}$.

Another potential mechanism for endothelial dysfunction during HHcy is inhibition of nitric oxide production caused by asymmetric dimethylarginine (ADMA), an analogue of L-arginine that acts as competitive inhibitor of eNOS ${ }^{(22)}$.

The plasma levels of NO in group III which had the folic acid as a prophylaxis and group IV which took the folic acid as a treatment were higher than that of group II, this shows that folic acid could improve the plasma NO bioavailability. However, folic acid can increase NO production by NO synthase as it has been suggested that folic acid increases endogenous regeneration of tetrahydrobiopterin, an essential cofactor for NO synthase. The effect of folate may result in decreased $\mathrm{NO}$ synthase- dependent $\mathrm{O}_{2}^{-}$formation as well as increased NO productio ${ }^{(23)}$. Folate has been also suggested to be involved in endogenous regeneration of $\mathrm{BH}_{4}$, an essential cofactor for $\mathrm{NO}$ synthase. The plasma levels of NO of group III was higher than that of group IV and this indicates that folic acid act as a prophylaxis better than as a treatment.

Oxidative stress may contribute to the deleterious effect of HHcy. HHcy induces endothelial cell injury through an oxidant - mediated mechanism, as Oxidative stress can stimulates NF-KB which regulated the expression of various genes involved in the inflammatory response of atherosclerosis, such as VCAM-1 (24).The results showed that the levels of Ery. SOD activity in group II were significantly decreased than other studied groups, this was due to that HHcy inhibits the antioxidant potential of the cells so it inhibits the levels of Ery. SOD activity. HHcy also induces cell injury/dysfunction through a mechanism involving autooxidation and oxidative damage. Folic acid supplementation as a prophylaxis in group III has a potent antioxidant effect which was evidenced by elevation of the levels of Ery. SOD activity of these group to the control levels but it did not occur when it was used as a treatment in group IV.

\section{Conclusions}

Dietary load of methionine has been shown to elevate plasma levels of t-Hcy in mice. This HHcy contributes to the early stage of atherosclerosis which was confirmed by increased expression of VCAM-1.

Plasma levels of t-Hcy might be a marker for atherosclerotic lesion in major arterial locations. Folic acid intake at levels in dietary supplements provides better protective effect of HHcy - induced atherosclerosis than its role as a treatment.

Our available data strongly suggest a benefit of folate supplementation in lowering cardiovascular diseases.

\section{Recommendations:}

Increased folate intake (a diet rich in vegetables and citrus fruit) is highly recommended in old age persons, hypertensive patients and people with high risk of atherosclerosis.

The potential role of oral folic acid therapy as a novel, safe and inexpensive tool to reduce 
cardiovascular risk should be further explored in other future studies.

\section{REFERENCES}

1. Selhub J (1999): Homocysteine metabolism. Annu Rev Med; 19: 217-224 .

2. Ross R (1999): Atherosclerosis an inflammatory disease. N. Engl. J. Med.340: 115- 126.

3. Ueland PM, Refsum $H$, Beresford SAA and Vollset SE (2000): The controversy over homocysteine and cardiovascular risk. Am. J. Clin. Nutr. 72: 324 332.

4. Zhou J, Moller J, Danielsen CC, Bentzon J, Ravn HB, Austin RC and Falk E (2001): Dietary supplementation with methionine and homocysteine promotes Early Atherosclerosis but not plaque rupture in ApoEdeficient Mice. Arterioscler Thromb Vasc Biol.; 21:14701476.

5. Price DT and Lascalzo J (1999): Cellular adhesion molecules and atherogenesis. Am J Med; 107:85-97.

6. Poddar $\mathbf{R}$, Sivasubramanian, $\mathbf{N}$, DiBello P, Robinson K. \& Jacobsen D W (2001): Homocysteine induces expression and secretion of monocyte chemoattractant protein-1 and interleukin-8 in human aortic endothelial cells: implications for vascular disease. Circulation 103:2717-2723.

7. Wang G, Siow YL and $\mathbf{O}$. (2001): Homocysteine induces monocyte chemoattractant protein-1 expression by activating
NF-kB in THP-1 macrophages. Am. J. Physiol. Heart. Circ. Physiol. 280:H2840-H2847.

8. Verhaar MC, Stores E ,Rabelink T.J (2002): Folates and cardiovascular. Arterioscler Thromb Vasc. Biol.; 22:6-13.

9. Frantzen F, Faaren AL, Alfhein I and Nordhei AK (1998): An enzyme conversion immunoassay for determining total homocysteine in plasma or serum. Clin.Chem.; 44:311.

10. Allain CC, Poom LS, Chan SG, Richmond $W$ and Fu PC (1974): Quantitative enzymatic colorimeteric determination of total and HDL cholesterol in serum or plasma. Clin.Chem; 20:470-475.

11. Wahlefeld AW (1974): Quantitative enzymatic colorimetric determination of triglycerides in serum or plasma .In: Methods of enzymatic analysis. Bergmeyer, H.U. Academic press, New York, vol.5, PP 1831-1835.

12. Finely PR (1978): Enzymatic determination of HDL-C .Clin.Chem., 24:931-934.

13. Feidewald WT, Levy RJ and Fredrickson DS (1972): Estimation of the concentration of low density lipoprotein cholesterol in plasma without use of the preparative ultracentrifuge. Clin. Chem ; 18:499-502.

14. Ding AH, Nathan $C F$ and Stuehr DJ (1988): Release of reactive nitrogen intermediates and reactive oxygen intermediates from mouse peritoneal machrophages.Comparison of 
activity cytokines and evidence of independent production. J. Immuno; 141:2407 -2412.

15. Misra HP and Fridovich (1976): The role of superoxide anion in the autoxidation of epinephrine and a simple assay for superoxide anion. J.Biol.Chem.; 247(10):31703175.

16. Sarhan AE, EL-Shabrawi A and El-Kashlan KM (1969): Intoduction of statistical methods in medicine and public health $.2^{\text {nd }}$ ed., University Book House, Alexandria.

17. Hirche FA, Schroder A, Knoth $B$, Stangl GI and Eder $K$ (2006): Effect of dietary methionine on plasma and liver cholesterol concentrations in rats and expression of hepatic genes involved in cholesterol metabolism. British Journal of Nutrition; 95, 879-888.

18. Stary HC, Chandler A B, Glagov S, Guyton JR, Insull, W, Rosenfeld, M E, Schaffer S A, Schwartz CJ, Wagner WD and Wissler RW (1994): A definition of initial, fatty streak, and intermediate lesions of atherosclerosis. A report from the Committee on Vascular Lesions of the Council on Arteriosclerosis, American Heart Association. Circulation 89:24622478.

19. Zulli A, Widdop RE, Hare DL, Buxton BF and Black MJ (2003): High Methionine and
Cholesterol Diet Abolishes

Endothelial Relaxation. sArterioscler Thromb Vasc Biol. 2003;23:1358-1363.

20. Lentz SR (2001): Homocysteine and cardiovascular physiology In Homocysteine in Health and Disease. Carmel R, Jacobsen DW (eds) (Cambridge, UK: Cambridge University Press).

21. Faraci FM and Lentz SR (2004): Hyperhomocysteinemia, oxidative stress, and cerebral vascular dysfunction Engl. J. Med. 338: 1042-1050

22. Stuhlinger MC, Oka RK, Graf EE, Schmolzer I, Upson BM, Kapoor O, Szuba A, Malinow MR, Wascher TC, Pachinger $O$ and Cooke JP (2003): Endothelial dysfunction induced by hyperhomocysteinemia: role of asymmetric dimethylarginine. Circulation 108: 933-938 Nature 320: 454-456.

23. Wilmink HW, Stroes ES, Erkelens WD, Gerritsen WB, Wever R, Banga JD, Rabelink TJ (2000): Influence of folic acid on postprandial endothelial dysfunction. Arterioscler Thromb Vasc Biol. 20:185-188.

24. Zhang R, Ma J, Xia M, Zhu H and Ling $W$ (2004): Mild hyperhomocysteinemia induced by feeding rats diets rich in methionine or deficient in folate promotes early atherosclerotic inflammatory processes .J. Nutrition ; 134:825-830. 


\section{دور التغذية المدعمة بالميثايونين و حامض الفوليك فى تصلب الشرايين المبكر لاى ذكور الفئران البالغين}

مروه عبد العزبز أحمد- منال محمد سبي"* علا محمود عمران**-هبه محمد سعد الدين* قسم الفسيولوجيا- قسم الهستولوجيا*- قسم الباثولوجيا** - كلية الطب - جامعة أسيوط

يعتبر إرتفاع مستوى الهوموسستيين فى الدم عاملا خطرا لمرض تصلب الشرايين .ولقد أثثتت الدراسات وجود تأثير مفيد لحامض الفوليك للوقاية من أمراض القلب والجهاز الدورى. وبهدف هذا البحث إلى تقييم العلاقة بين مستوى الهوموسستيين فى البلازما و تصلب الثرايين المبكرلدى ذكور الفئران البالغين وهل تأثنير الهوموسستين يكون من خلال الجزىء الوعائى الخلوى الملتصق - ا ام لا. وإلى تقييم العلاقة بين مستوى الهوموستنيين فى البلازما و مستوى حامض الفوليك وتحديد تأثنر حامض الفوليك فى الوقايةوالعلاج من تصلب الثرايين المبكر • و لقد أجريت هذه الدراسة على •ع فار من الذكور البالغين نم تقسيمهر عشوا ئيا غلى ؛ مجموعة(• (فئران فى كل مجموعة) مجموعة ا وقد نم تغذيتهم بغذاء معيارى و مثلت المجموعة الضابطة ـ مجموعة ب وقد تم إعطاؤها ميثايونين بتركيز ع. ع٪ / لتز ماء لمدة 1 أسابيع. مجموعة r:وتتاولوا ميثايونين (ع.ع \%/لتر ماء) مع حمض الفوليك بتركيز / جم / كجم

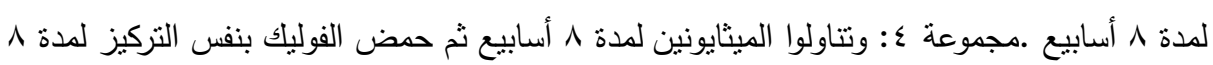
أسابيع أخرى.

وقد تم قياس مستويات الهوموسستين و تركيز الدهون في أمصال الفئران،كما تم قياس مستويات أكسيد النيتريك و سوبرأكسيد ديسميونيز . بالأضافة لأخذ عينات من أنسجة الشريان الأورطى من جميع الفئران وتم فحص التغيرات

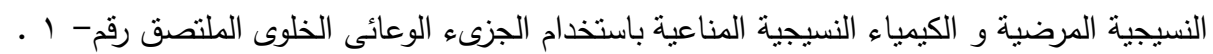

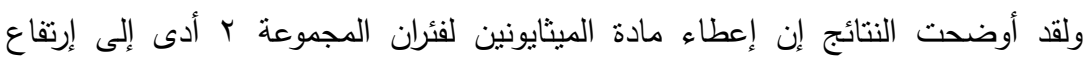
مستويات الهوموسستين فى البلازما إرتفاعا ذو دلالة إحصائية مما أدى إلى إرتفاع فى مستويات الكولستيرول لاى هذه الفئران. و كان هناك نقص فى مستويات أكسيد النيتزيك و سوبر أكسيد النيتريك.وعند فحص أنسجة شريان الأورطى لهذه الفئران وجد ت تغيرات نسيجية مرضية مبكرة لمرض فئرون التصلب الثربانى كما صاحب ذلك زيادة فى التعبير المناعى الهستوكيميائى للجزىء الوعائى الخلوى

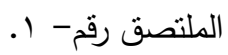


وأوضحت النتائج أن إستخدام حمض الفوليك لفئران الهموعتين r,ء أدى إلى إنخفاض

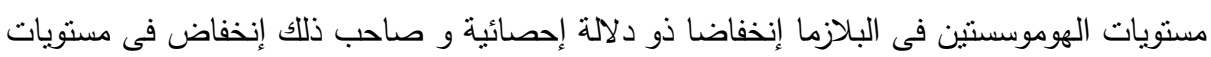
الكولستيرول لدى هذه الفئران. وزيادة فى مستويات أكسيد النيتريك و سوبر أكسيد

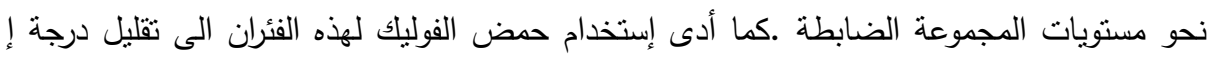

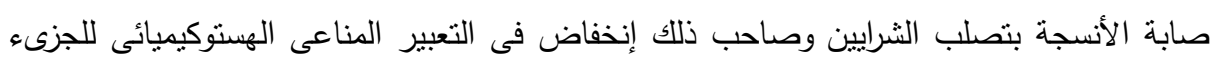

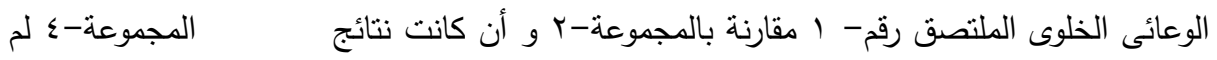
تصل إلى نفس مستوى المجموعة الضابطة. ونستتنج من هذه الدراسة أن زيادة مستويات الهوموسنتين فى الدم تؤدى إلى الأصابة

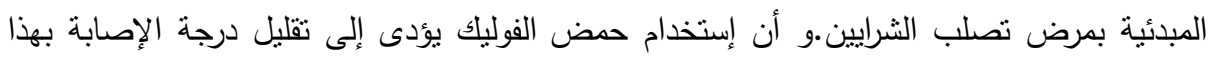

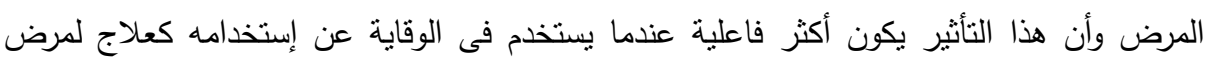
تصلب الثرايين.

ويوصى باستخدام حمض الفوليك (الخضر و الفاكهة) لكبار السن و مرضى ضغط الدم والمعرضين لحدوث تصلب الثرايين. 